This item was submitted to Loughborough's Research Repository by the author.

Items in Figshare are protected by copyright, with all rights reserved, unless otherwise indicated.

\title{
Safety risks associated with physical interactions between patients and caregivers during treatment and care delivery in Home Care settings: a systematic review
}

\section{PLEASE CITE THE PUBLISHED VERSION}

http://dx.doi.org/10.1016/j.jinurstu.2016.02.011

\section{PUBLISHER}

(C) Elsevier

\section{VERSION}

AM (Accepted Manuscript)

\section{PUBLISHER STATEMENT}

This work is made available according to the conditions of the Creative Commons Attribution-NonCommercialNoDerivatives 4.0 International (CC BY-NC-ND 4.0) licence. Full details of this licence are available at: https://creativecommons.org/licenses/by-nc-nd/4.0/

\section{LICENCE}

CC BY-NC-ND 4.0

\section{REPOSITORY RECORD}

Hignett, Sue, Mary Edmunds Otter, and Christine Keen. 2019. "Safety Risks Associated with Physical Interactions Between Patients and Caregivers During Treatment and Care Delivery in Home Care Settings: A Systematic Review". figshare. https://hdl.handle.net/2134/20433. 
Safety risks associated with physical interactions between patients and caregivers during treatment and care delivery in Home Care settings: a systematic review

Authors: Sue Hignett*a, Mary Edmunds Otter ${ }^{\mathrm{b}}$, Christine Keen $^{\mathrm{c}}$

${ }^{1}$ Loughborough University, UK; ${ }^{2}$ Leicester University, UK; ${ }^{3}$ De Montfort University, UK.

*Corresponding Author

$\mathrm{a}^{*}$ Prof. Sue Hignett

Professor of Healthcare Ergonomics \& Patient Safety

Loughborough Design School

Loughborough University,

Loughborough, Leics.UK.

LE11 3TU

Tel: +44 (0)1509 223003

Email: S.M.Hignett@lboro.ac.uk

${ }^{b}$ Mary Edmunds Otter

NIHR RDS East Midlands

Dept. of Health Sciences

University of Leicester

Leicestershire, UK

Email: mleo1@leicester.ac.uk

${ }^{c}$ Christine Keen

NIHR RDS East Midlands

Faculty of Health \& Life Sciences

De Montfort University

Leicestershire, UK

Email: ckeen@dmu.ac.uk 


\title{
Safety risks associated with physical interactions between patients and caregivers during treatment and care delivery in Home Care settings: a systematic review
}

\begin{abstract}
Objective: To explore the safety risks associated with physical interactions between patients and caregivers during treatment and care delivery in Home Care settings Design: Seven-stage framework from the PRISMA statement for research question, eligibility (definition), search, identification of relevant papers from title and abstract, selection and retrieval of papers, appraisal and synthesis.
\end{abstract}

Data sources: British Nursing Index (BNI), Allied and Complementary Medicine Database (AMED), Applied Social Sciences Index and Abstracts (ASSIA), Cinahl, Cochrane Library, Embase, Ergonomics Abstracts, Health Business Elite, Health Management Information Consortium (HMIC), Medline, Psyclnfo, Scopus, Social Care online, Social Science Citation Index).

Review methods: The included references $(n=42)$ were critically appraised using a modified version of Downs and Black checklist and the Mixed Methods Appraisal Tool.

Results: The risk factors are reported using the modified model of human factors of health care in the home to represent the roles of both patients and caregivers in the system. The results are grouped as environment (health policy, physical and social), artefacts (equipment and technology), tasks (procedures and work schedules) and care recipient/provider. These include permanent and temporary building design and access, communication and lone working, provision of equipment and consumables, and clinical tasks. The topics with strong evidence from at least 2 papers relate to risks associated with awkward working positions, social environment issues (additional tasks and distractions), abuse and violence, inadequate team (peer) support, problems with workload planning, needle stick injuries and physical workload (moving and handling patients).

Conclusions: As home care increases, there is a need to ensure the safety of both patients and caregivers with an understanding of the physical interactions and tasks to manage safety risks and plan safer care delivery systems. 


\section{Keywords}

Home care services, moving and lifting patients, patient safety, occupational health, community health services

\section{Highlights}

What is already known:

- Providing care and treatment at a patient's home presents risks to both caregivers and patients whether care is delivered from one or multiple organisation(s).

- There are different models of home care, including the hospital in the home, patient-centred medical home, home first policies and aging-in-place

- Care tasks are categorised as basic care, including personal hygiene, mobilisation, nutrition and social company, and advanced care, including medication administration, tube feeding, and operating home care technology (e.g. ventilator, electric wheelchair)

What this paper adds

- Risk factors for the environment of care are associated with health policies, physical location and social environment.

- The risks include permanent and temporary building design and access, communication and lone working, provision of equipment and consumables and clinical tasks.

- As home care increases, there is a need to ensure the safety of both patients and caregivers with an understanding of the physical interactions and tasks to manage risks and plan safer care delivery systems. 


\section{Introduction}

'A person's home is not just the place where they live, but also a place of work for home care workers' (Taylor and Donnelly, 2006). Planning and policy makers, guided by both patient (care recipient) preference for care and treatment in their own home and cost-containment pressures, have been increasingly focussing on community care (Craven et al, 2012; EU-OSHA, 2014). Initiatives have been implemented since the 1960 s as deinstitutionalization, community care, continuous care, integrated care and home-based care (WHO, 2008). Home care aims to satisfy peoples' health and social needs in their homes by 'providing appropriate and highquality home-based healthcare and social services, by formal and informal caregivers, with the use of technology when appropriate, within a balanced and affordable continuum of care' (WHO, 2008). However the home setting presents challenges for the more established (acute) caregiver-patient interactions and requires adaptation of policies, protocols and routines (Duke et al, 2012). The labelling of services as either social care or healthcare depends on the characteristics and boundaries of both systems and varies in different countries. In 2012 in England there were over 1.1 million people receiving care at home from approx. 1.8 million formal and 5 million informal caregivers (Department of Health, 2012). A study of elderly care in France (Davin et al, 2005) found that 'more than 1 million people aged 60 years and older need assistance from another person to perform at least one $A D L$ [activity of daily living] (bathing, dressing, going to toilet, eating, transferring, getting outside) and about 2.5 million persons for at least one $I A D L$ [instrumental activities of daily living] (shopping, food preparation, housekeeping)'. Care tasks have been categorised as basic and advanced, where basic care includes personal hygiene, mobilisation, nutrition and social company and advanced care has a more clinical focus including medication administration, tube feeding, and operating home care technology (ventilator, electric wheelchair, bedlifts, oxygen devices) (Swedberg et al, 2013; EU-OSHA, 2014).

There are different models of home care, for example, hospital in the home (Duke et al, 2012), patient-centred medical home (Bitton et al, 2012) home first policies and aging-in-place (Craven et al, 2012). One of the challenges to providing care and treatment at the patient's home is the safety and risk of injury to caregivers and patients when care is delivered by staff working alone (HSE, 2009) or as part of a 
team (Simon et al, 2008). This could be within one organisation (Markkanen et al, 2007), interagency working (Miller and Cameron, 2011) or student supervision (Leh, 2011).

This paper reports the method and results for a systematic literature review to consider caregiver and patient safety and injury risks associated with physical interactions during home care and treatment in the community. It includes a wide range of care procedures from treatment (e.g. palliative care) to daily living care (hygiene and mobility). The term 'patient' is used to refer to the care recipient.

\section{Method}

A seven-stage framework was used in line with the PRISMA statement (www.prisma-statement.org) for research question, eligibility (definition), search, identification of relevant papers from title and abstract, selection and retrieval of papers, appraisal and synthesis.

\section{Research question}

The question addressed in this review is 'What are the safety risks associated with physical interactions between patients and caregivers during treatment and care delivery in Home Care settings?'

\section{Eligibility (inclusion/exclusion)}

References were screened at the first stage by setting the database search parameters to all languages where the paper had an English abstract, (1980-), worldwide (region), adult (age range) and any study type.

\section{Search}

The complexity of the topic proved challenging for literature searching. The first stage was a scoping exercise to explore and test the literature available for the key concepts associated with the research question. This included defining caregivers, context and activities by examining terminology used in published literature (e.g. Craib et al, 2007) so could include formal caregivers, nurses, home care assistants, home care support workers, social care workers, medical social workers, district nurses, occupational therapists and physiotherapists. The types of activities 
included bathing, dressing wounds, activities of daily living, getting people in or out of bed, functional care, and physical care.

The first set of keywords were tested in preliminary searches for Medline and ASSIA using the following example string search: (housebound OR homebound OR "community care" OR domiciliary OR "home care" OR "house bound" OR house OR "home health*") AND ("lifting and moving patients" OR "mov* patient*" OR lifting OR "patient handling" OR "manual handling") AND (safety OR injury* OR risk* OR occupational). The results were reviewed for relevance and additional keywords were added from retrieved references.

The searches were then divided into three areas to combine concepts for safety $(A+B+C)$, working practices $(A+B+D)$ and equipment $(A+B+E)$.
A. Patients in their own home
B. Patient handling/moving and lifting
C. Safety, risks, injuries (patients and caregivers)
D. Working practices (solo working, team work etc.)
E. Use of equipment (hoists, lifts etc.)

The Medline search was adapted and then the same search string was used in HMIC, Health Business Elite, British Nursing Index (BNI) and Allied and Complementary Medicine Database (AMED). The Applied Social Sciences Index and Abstracts (ASSIA) search was also revised and extended, resulting in 3 strings (Figure 1). These formed the basis for searching Psyclnfo, Scopus, Cochrane Library and Social Science Citation Index (SSCI, Web of Science). Minor modifications were needed for individual databases; in Scopus and SSCI the terms domestic and positioning were removed as they resulted in many irrelevant references. 'Domestic' mapped to financial markets and 'Positioning' automatically truncated to position which brought up hundreds of irrelevant references. In order to limit searches to references about humans (Scopus includes agriculture and veterinary literature) an additional line was added to the 3 searches: (patient* OR

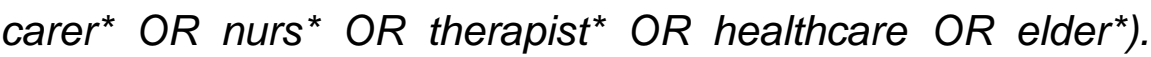

The full search strategy was run on 14 databases: AMED, ASSIA, BNI, Cinahl, Cochrane Library, Embase, Ergonomics Abstracts, Health Business Elite, Health Management Information Consortium (HMIC), Medline, Psyclnfo, Scopus, Social 
Care online, SSCI and supplemented by other search strategies (e.g. exploding reference lists).

\begin{abstract}
Search 1.
(housebound OR homebound OR "community care" OR domiciliary OR "home care" OR "house bound" OR house OR "home health*" OR domestic OR "district nurs*" OR "at home" OR "own home*") AND ("lifting and moving patients" OR "mov* patient*" OR lifting OR "patient handling" OR "manual handling" OR "assisted mobility" OR "people handling" OR positioning OR reposition* OR turning) AND (safety OR injury* OR risk* OR occupational OR accident* OR "health and safety" OR exert* OR overexert* OR strain* OR "back pain" OR "neck pain")
\end{abstract}

\title{
Search 2
}

(housebound OR homebound OR "community care" OR domiciliary OR "home care" OR "house bound" OR house OR "home health*" OR domestic OR "district nurs*" OR "at home" OR "own home*") AND ("lifting and moving patients" OR "mov* patient*" OR lifting OR "patient handling" OR "manual handling" OR "assisted mobility"OR "people handling" or positioning OR reposition* OR turning) AND (solo or lone or alone or team* or "with help" or "without help")

\section{Search 3}

(housebound OR homebound OR "community care" OR domiciliary OR "home care" OR "house bound" OR house OR "home health*" OR domestic OR "district nurs*" OR "at home" OR "own home*") AND ("lifting and moving patients" OR "mov* patient*" OR lifting OR "patient handling" OR "manual handling" OR "assisted mobility" OR "people handling" OR positioning OR reposition* OR turning) AND (equipment OR hoist* OR sling* OR sheet* OR ergon* OR belt* OR device* OR mechan* OR engineer* OR "bath* aid" OR "hygiene aid")

Figure 1. String searches for ASSIA, PsycInfo, Scopus, Cochrane Library, Social Science Citation Index

The search from each database was imported into a shared RefWorks (https://www.refworks.com) account (for all authors). This central database was then checked for duplication and the references were screened by title and abstract.

\section{Identification of relevant papers from titlelabstract}

The inclusion/exclusion criteria were adapted during the review process (emerging exclusion criteria) and the full dataset was checked for inclusion/exclusion before proceeding to critical appraisal.

References were included if they investigated, reported or reviewed:

1. Home care and treatment in the community. 
2. Safety events or risks associated with interactions between patients and caregivers during physical care delivery.

3. Solo or team working for clinical treatment or care task (including physical assistance, medication or equipment checking activities).

References were excluded where:

- Location of care was hospital care, nursing home, residential care homes, and ambulance or emergency care.

- Citations were published as dissertations, conference abstracts or professional opinions.

- Care was only provided by informal caregivers (e.g. family).

- Only patient safety issues were discussed e.g. unwitnessed falls or development of pressure sore (no physical interaction).

- Care involved:

- Remote monitoring technology rather than delivering care, for example falls sensors (accelerometers), dementia location (wandering) monitors and cardiac monitors.

- Pharmacy/medication errors unless being directly administered by a caregiver (e.g. team to check).

- Discharge planning and transitions-in-care (e.g. pre-discharge home visit).

- Live-in care for people with learning disabilities.

- Emergency response.

- Solo working with respect to personal safety due to domestic violence and/or aggression.

- Solo working with respect to travel to/from patient.

\section{Selection and retrieval of papers}

The database search produced 1613 references (Table 1 ). These were screened by title and abstract and checked for duplication (in RefWorks) resulting in 338 included papers. The screening and eligibility stages both reduced the number of references and also added papers by exploding relevant reference lists from individual papers (Figure 2). 
Table 1. Search results

\begin{tabular}{lccc}
\hline Database (Provider) & Results & Reviewed by title & $\begin{array}{c}\text { Reviewed by } \\
\text { Abstract }\end{array}$ \\
\hline AMED (NHS Evidence) & 59 & 22 & 11 \\
ASSIA (Proquest) & 59 & 10 & 8 \\
BNI (NHS Evidence) & 10 & 7 & 5 \\
Cinahl (NHS Evidence) & 42 & 19 & 14 \\
Cochrane Library & 121 & 10 & 8 \\
CENTRAL (Wiley) & & & \\
Embase (Ovid SP) & 172 & 51 & 32 \\
Ergonomics abstracts & 215 & 23 & 21 \\
Health Business Elite & 61 & 10 & 5 \\
(NHS Evidence) & & & 5 \\
HMIC (NHS Evidence) & 23 & 5 & 152 \\
Medline (Ovid SP) & 447 & 172 & 6 \\
Psyclnfo (EBSCO) & 24 & 8 & 45 \\
Scopus (Elsevier) & 209 & 49 & 10 \\
Social care online (SCIE) & 96 & 13 & 16 \\
SSCl & 75 & 18 & 338 \\
\hline TOTAL & 1613 & 417 & \\
\hline
\end{tabular}

\section{Appraisal: Mixed Methods Appraisal Tool and modified Downs \& Black} (1998) checklist

The included references $(n=42)$ were critically appraised using a modified version of Downs and Black (1998) checklist (Hignett et al, 2003) and the Mixed Methods Appraisal Tool (Pluye et al, 2009; 2011). The Mixed Methods Appraisal Tool has been validated across qualitative, quantitative and mixed methods empirical studies. It allocates a score from 0-100 (in quartiles) where the overall quality for a mixed methods score cannot exceed the quality of the weakest component. The Downs and Black Checklist was used to cross-check the Mixed Methods Appraisal Tool, with agreement within quartiles and then recorded as strong (100\%), moderate (75\%) and limited (50\%) evidence. 


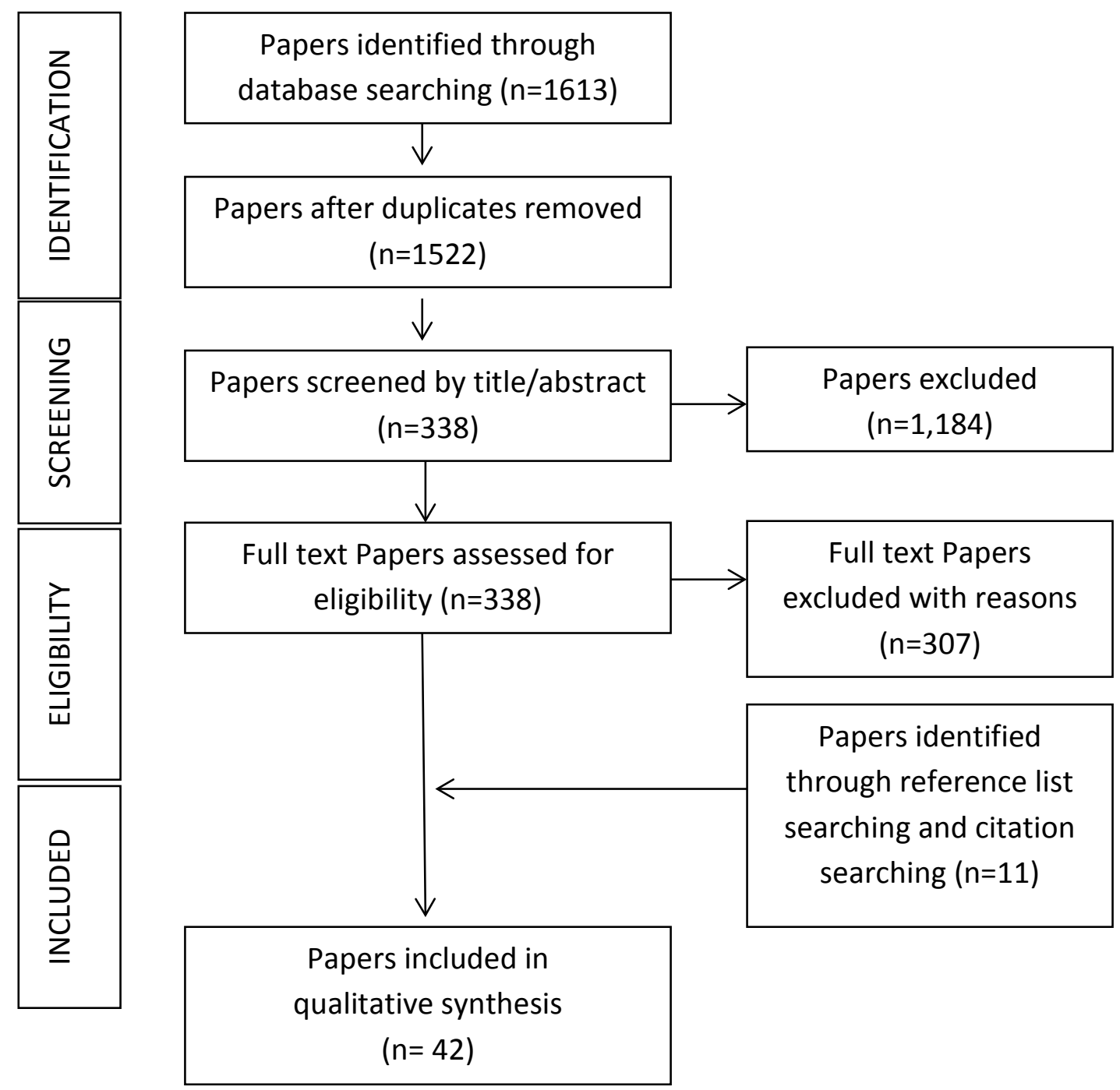

Figure 2. PRIMSA flow chart

Following critical appraisal, two papers were excluded with a low critical appraisal score (less than 50\%). Three other papers were excluded as a preliminary baseline study where the follow-up paper was included (Beer et al, 2014; Brulin et al, 2001; Knibbe and Friele, 1999). This resulted in the 37 included papers listed in Table 2 for a qualitative synthesis. A quantitative synthesis is not included due to the diversity of study types, populations studied and variance in definitions of home care provision. 
Table 2. Included papers $\left({ }^{\star \star *}\right.$ strong evidence, ${ }^{\star \star}$ moderate evidence and ${ }^{\star}$ limited evidence)

\begin{tabular}{|c|c|c|c|c|c|}
\hline Author & $\begin{array}{l}\text { Study } \\
\text { type }\end{array}$ & Aim & Study population & Study design & Key findings \\
\hline $\begin{array}{l}\text { 1. Alamgir et al, } \\
2007 \text { [Canada] } \\
\star \star \star\end{array}$ & $\begin{array}{l}\text { Exploratory } \\
\text { secondary } \\
\text { database }\end{array}$ & $\begin{array}{l}\text { To examine how injury } \\
\text { rates and types differ } \\
\text { across direct care } \\
\text { occupations in relation to } \\
\text { healthcare settings in } \\
\text { Canada }\end{array}$ & $\begin{array}{l}\text { I year incident } \\
\text { data resulting in } \\
\text { time loss or } \\
\text { medical care from } \\
3 \text { large health } \\
\text { regions }\end{array}$ & $\begin{array}{l}\text { Merged data from payroll, } \\
\text { compensation claims and } \\
\text { incidence reports as } \\
\text { secondary data analysis } \\
\text { with denominator of } \\
\text { productive hours for } \\
\text { Registered Nurses } \\
\text { (RNs), Licensed Practice } \\
\text { Nurses (LPNs) and Care } \\
\text { Assistants }\end{array}$ & $\begin{array}{l}\text { RNs were the least vulnerable for injuries in } \\
\text { all sectors. Care Assistants were the most } \\
\text { vulnerable. Home care rates were lower than } \\
\text { both acute care and nursing homes }\end{array}$ \\
\hline $\begin{array}{l}\text { 2. Beer et al, } 2014 \\
\text { [US] }\end{array}$ & $\begin{array}{l}\text { Descriptive } \\
\text { qualitative }\end{array}$ & $\begin{array}{l}\text { To use a systems model } \\
\text { to frame the challenges } \\
\text { discussed by home care } \\
\text { workers }\end{array}$ & $\begin{array}{l}8 \text { certified nursing } \\
\text { assistants, } \\
8 \text { RNs }\end{array}$ & $\begin{array}{l}\text { Structured interviews } \\
\text { about } 7 \text { tasks: medication } \\
\text { management, transfer, } \\
\text { bathing, toileting, wound } \\
\text { care, infusion pump, } \\
\text { device use. }\end{array}$ & $\begin{array}{l}\text { Challenges related to care recipient needs } \\
\text { for health-related decline or emotional stress } \\
\text { e.g. physical / cognitive limitation. } \\
\text { Developed Human Factors \& Ergonomics } \\
\text { care model }\end{array}$ \\
\hline $\begin{array}{l}\text { 3. Brown \& Mulley, } \\
1997 \text { [UK] } \\
\text { * }\end{array}$ & $\begin{array}{l}\text { Descriptive } \\
\text { survey }\end{array}$ & $\begin{array}{l}\text { To describe the } \\
\text { occurrence of physical } \\
\text { injuries experienced by } \\
\text { informal caregivers whilst } \\
\text { moving \& handling }(\mathrm{M} \& \mathrm{H}) \\
\text { their elderly dependents }\end{array}$ & $\begin{array}{l}46 \text { informal } \\
\text { caregivers }\end{array}$ & In-depth interviews & $\begin{array}{l}38 \text { caregivers received personal assistance } \\
\text { with M\&H from family (26), home care } \\
\text { services (20), friends/neighbours (16), district } \\
\text { nurse (12). } 16 \text { patients had been injured } \\
\text { when being lifted/handled. } 19 \text { caregivers } \\
\text { had been instructed on } M \& H ; 15 \text { informally } \\
\text { during treatment session ( } 3 \text { on hoist). No } \\
\text { caregivers aware of formal training } \\
\text { packages; no handling techniques had been } \\
\text { assessed. }\end{array}$ \\
\hline $\begin{array}{l}\text { 4. Brulin et al, } \\
2001 \text { [Sweden] } \\
\star \star \star *\end{array}$ & Survey & $\begin{array}{l}\text { To investigate physical } \\
\text { and psychosocial risk } \\
\text { factors and whether } \\
\text { psychosocial factors } \\
\text { could predict } \\
\text { musculoskeletal } \\
\text { disorders (MSD) after } 5 \\
\text { years }\end{array}$ & $\begin{array}{l}234 \text { home care } \\
\text { workers }\end{array}$ & Questionnaire & $\begin{array}{l}\text { Best predictor of low back problems was } \\
\text { previous episode. Lack of involvement in } \\
\text { work planning increased physical complaints. } \\
\text { Risk factors include workload planning, M\&H } \\
\text { patients, awkward working positions and } \\
\text { working alone. }\end{array}$ \\
\hline $\begin{array}{l}\text { 5. Cheung et al, } \\
2006 \text { [Hong } \\
\text { Kong] }\end{array}$ & $\begin{array}{l}\text { Exploratory } \\
\text { cross- } \\
\text { sectional } \\
\text { study }\end{array}$ & $\begin{array}{l}\text { To identify the magnitude } \\
\text { of, and risk factors for, } \\
\text { back pain in Hong Kong } \\
\text { Home Care Nursing } \\
\text { personnel }\end{array}$ & 411 & $\begin{array}{l}\text { Self-reported workload, } \\
\text { Nordic Questionnaire, } \\
\text { functional outcomes, } \\
\text { psychosocial factors }\end{array}$ & $\begin{array}{l}\text { Annual prevalence for back pain was } 71 \% \text {. } \\
\text { Three predictors: (1) physical risk factors in } \\
\text { office, (2) static postures, ( } 3 \text { ) psychosocial } \\
\text { job demands. Not primarily associated with } \\
\text { patient lifting and transfers }\end{array}$ \\
\hline
\end{tabular}




\begin{tabular}{|c|c|c|c|c|c|}
\hline $\begin{array}{l}\text { 6. Conneeley, } \\
1998 \text { [UK] } \\
\text { * }\end{array}$ & Exploratory & $\begin{array}{l}\text { To explore implications of } \\
\text { Manual Handling } \\
\text { Operations Regulations } \\
\text { for use of hoist in } \\
\text { community }\end{array}$ & 10 patients & $\begin{array}{l}\text { Qualitative interviews } \\
\text { with thematic analysis }\end{array}$ & $\begin{array}{l}\text { Hoist was seen to be less intrusive than the } \\
\text { number of staff previously required ( } 1 \\
\text { participant). Hoist incompatible with } \\
\text { environment (size and aesthetics) and } \\
\text { constant reminder of loss of function }\end{array}$ \\
\hline $\begin{array}{l}\text { 7. Craib et al, } \\
2007 \text { [Canada] } \\
\star \star \star *\end{array}$ & $\begin{array}{l}\text { Interventio } \\
\mathrm{n}\end{array}$ & $\begin{array}{l}\text { To determine the } \\
\text { incidence of workplace } \\
\text { injury among community } \\
\text { health workers; to identify } \\
\text { predictors of injury; to } \\
\text { assess the effectiveness } \\
\text { of a multicomponent } \\
\text { intervention }\end{array}$ & $\begin{array}{l}648 \text { home care } \\
\text { staff at } 5 \text { agencies } \\
\text { with } 6^{\text {th }} \text { as control }\end{array}$ & $\begin{array}{l}\text { Questionnaire. } \\
\text { Interventions: } \\
\text { (1) education \& training } \\
\text { (E\&T); } \\
\text { (2)Risk Assessment (RA) } \\
\text { tool; } \\
\text { (3) Lift (hoist) equipment } \\
\text { registry (loan). }\end{array}$ & $\begin{array}{l}\text { Lifts were rarely used so combined groups to } \\
\text { compare E\&T versus E\&T/RA tool. Annual } \\
\text { incidence of reported injuries was } 20 \% \text { (time } \\
\text { lost injuries }=8 \% \text { ). Most injuries attributable } \\
\text { to over exertion }\end{array}$ \\
\hline $\begin{array}{l}\text { 8. Craven et al, } \\
2012 \text { [Canada] } \\
\text { ** }\end{array}$ & $\begin{array}{l}\text { Exploratory } \\
\text { qualitative }\end{array}$ & $\begin{array}{l}\text { To explore the types and } \\
\text { patterns of safety } \\
\text { concerns staff } \\
\text { encountered in home } \\
\text { care settings }\end{array}$ & $\begin{array}{l}115 \text { home care } \\
\text { staff }\end{array}$ & $\begin{array}{l}\text { Semi-structured } \\
\text { interviews }\end{array}$ & \multirow{2}{*}{$\begin{array}{l}\text { Safety concerns about abuse/violence, lack } \\
\text { of space, time pressures, provision of } \\
\text { equipment and consumables and M\&H. Care } \\
\text { is provided in unregulated, private } \\
\text { residences (living space = work space). } \\
\text { (1) Workload was significant in predicting } \\
\text { pain at end of shift; } \\
\text { (2) poor assessment agreement by nurses } \\
\text { for mobility }\end{array}$} \\
\hline $\begin{array}{l}\text { 9. Czuba et al, } \\
2012 \text { [US] }\end{array}$ & $\begin{array}{l}\text { Exploratory } \\
\text { mixed } \\
\text { methods }\end{array}$ & $\begin{array}{l}\text { To improve the } \\
\text { understanding of risk } \\
\text { factors that may lead to } \\
\text { injury and increased } \\
\text { turnover in home health } \\
\text { aides (HHAs); to discover } \\
\text { unexplained opportunities } \\
\text { for interventions; to test } \\
\text { those intervention ideas } \\
\text { for potential effects, } \\
\text { feasibility and } \\
\text { acceptance by HHAs and } \\
\text { their employers }\end{array}$ & $\begin{array}{l}\text { One provider } \\
\text { company. } \\
\text { Observations with } \\
17 \text { HHAs and } 36 \\
\text { patients. } \\
\text { Workshops with } \\
14 \text { HHAs. Pilot } \\
\text { intervention with } \\
21 \text { HHAs }\end{array}$ & $\begin{array}{l}\text { (1) Secondary analysis of } \\
\text { Workers Compensation } \\
\text { injury data; } \\
\text { (2) direct observation; } \\
\text { (3) participatory testing of } \\
\text { intervention to supply gait } \\
\text { belts, cleaning supplies, } \\
\text { and improve care plans } \\
\text { and workload distribution } \\
\text { for heavy patients }\end{array}$ & \\
\hline $\begin{array}{l}\text { 10. Dellve et al, } \\
2003 \\
\text { [Sweden] }\end{array}$ & $\begin{array}{l}\text { Exploratory } \\
\text { survey } \\
\text { retrospecti } \\
\text { ve case } \\
\text { control }\end{array}$ & $\begin{array}{l}\text { To explore and estimate } \\
\text { the impact of the work } \\
\text { system on permanent } \\
\text { work disability and its } \\
\text { relative importance } \\
\text { compared with home-life } \\
\text { risks among home care } \\
\text { workers }\end{array}$ & $\begin{array}{l}617 \text { home care } \\
\text { workers and } 771 \\
\text { matched controls } \\
\text { selected from } \\
\text { employers } \\
\text { database }\end{array}$ & Questionnaire & $\begin{array}{l}\text { Strongest risk factors included } \\
\text { abuse/violence, leadership and peer support, } \\
\text { policies/procedures, workload planning and } \\
\text { awkward working positions. }\end{array}$ \\
\hline
\end{tabular}




\begin{tabular}{|c|c|c|c|c|c|c|}
\hline 11. & $\begin{array}{l}\text { Denton et al, } \\
2002 \\
\text { [Canada] }\end{array}$ & Exploratory & $\begin{array}{l}\text { To examine the effects of } \\
\text { working in clients homes } \\
\text { on the mental health and } \\
\text { well-being of visiting } \\
\text { home care workers }\end{array}$ & $\begin{array}{l}674 \text { visiting } \\
\text { therapists, nurses } \\
\text { and home support } \\
\text { workers from } 3 \\
\text { home care } \\
\text { organisations }\end{array}$ & $\begin{array}{l}\text { Focus groups; } \\
\text { Questionnaire }\end{array}$ & $\begin{array}{l}\text { Workload, difficult clients who take } \\
\text { advantage with extra work requests. } \\
\text { Difficulties include cleanliness of workplace, } \\
\text { distrations, team support and M\&H of } \\
\text { patients }\end{array}$ \\
\hline 12. & $\begin{array}{l}\text { Faucett et } \\
\text { al, 2013 } \\
\text { [US] }\end{array}$ & $\begin{array}{l}\text { Exploratory } \\
\text { survey }\end{array}$ & $\begin{array}{l}\text { To identify functional, } \\
\text { temporal, physical and } \\
\text { relationship risk factors } \\
\text { for transient and chronic } \\
\text { conditions for MSDs and } \\
\text { injuries among Personal } \\
\text { Assistance Services } \\
\text { (PAS) providers }\end{array}$ & 855 PAS workers & $\begin{array}{l}\text { Survey based on Nordic } \\
\text { questionnaire, }\end{array}$ & $\begin{array}{l}58 \% \text { reported assisting with transfers bed- } \\
\text { chair, } \\
41 \% \text { reported } 1-10 \text { transfers per day, } \\
85 \% \text { reported no lifting equipment available. } \\
\text { Having more than } 2 \text { years experience } \\
\text { reduced the risk of acute problems but } \\
\text { increased the risk of greater chronicity }\end{array}$ \\
\hline 13. & $\begin{array}{l}\text { Galinsky et } \\
\text { al, 2010 } \\
\text { [US] }\end{array}$ & Survey & $\begin{array}{l}\text { To explore factors } \\
\text { associated with assaults } \\
\text { by patients on home } \\
\text { healthcare aides and } \\
\text { nurses }\end{array}$ & $\begin{array}{l}677 \text { home } \\
\text { healthcare aides } \\
\text { and nurses }\end{array}$ & Questionnaire & $\begin{array}{l}3 \text { risk factors were significant. } \\
\text { (1) having one or more patients with } \\
\text { dementia, } \\
\text { (2) routinely handling patients, } \\
\text { (3) perceiving threats of violence by others in } \\
\text { and around patients homes. 'Assaulted } \\
\text { workers and those perceiving threats were } \\
\text { significantly more likely to be have shortened } \\
\text { home visits'. }\end{array}$ \\
\hline 14. & $\begin{array}{l}\text { Hale \& } \\
\text { Piggot, } 2005 \\
\text { [New } \\
\text { Zealand] }\end{array}$ & $\begin{array}{l}\text { Exploratory } \\
\text { qualitative }\end{array}$ & $\begin{array}{l}\text { To explore the content of } \\
\text { present } \\
\text { physiotherapeutic home } \\
\text { intervention for people } \\
\text { with stroke that resulted } \\
\text { in the development of a } \\
\text { conceptual framework to } \\
\text { guide practice }\end{array}$ & $\begin{array}{l}20 \\
\text { physiotherapists }\end{array}$ & $\begin{array}{l}\text { Semi-structured } \\
\text { interviews }\end{array}$ & $\begin{array}{l}\text { Some worked alone, some worked in team. } \\
\text { Risks included lack of space, distrations, } \\
\text { safety concerns when working alone and } \\
\text { equipment provision/ }\end{array}$ \\
\hline
\end{tabular}




\begin{tabular}{|c|c|c|c|c|c|c|}
\hline $\begin{array}{l}15 . \\
*\end{array}$ & $\begin{array}{l}\text { Hoff, } 2013 \\
\text { [US] }\end{array}$ & $\begin{array}{l}\text { Exploratory } \\
\text { qualitative }\end{array}$ & $\begin{array}{l}\text { To gain a better } \\
\text { understanding of how } \\
\text { Patient-Centred Medical } \\
\text { Home (PCMH) principles } \\
\text { should be implemented } \\
\text { by different } \\
\text { subpopulations }\end{array}$ & $\begin{array}{l}51 \text { staff from } 6 \\
\text { practices; } 22 \\
\text { primary care } \\
\text { physicians, } 5 \\
\text { nurse } \\
\text { practitioners, } 7 \\
\text { practice } \\
\text { managers, } 6 \text { RNs, } \\
7 \text { LPN, } 3 \text { medical } \\
\text { assistants, } 2 \\
\text { clinical quality } \\
\text { supervisors }\end{array}$ & Interviews & $\begin{array}{l}\text { Two domains of 'hard' and 'soft' PCMH } \\
\text { implementation practices. } \\
\text { 'Hard' = more standardised, use of formal } \\
\text { work protocols e.g. medicines reconciliation, } \\
\text { discharge planning; } \\
\text { 'Soft' = knowing the patient, empathy and } \\
\text { compassion, using family, tailored } \\
\text { communication approaches }\end{array}$ \\
\hline 16. & $\begin{array}{l}\text { Howard \& } \\
\text { Adams, } \\
2010 \text { [US] }\end{array}$ & $\begin{array}{l}\text { Exploratory } \\
\text { survey } \\
\text { secondary } \\
\text { data } \\
\text { analysis }\end{array}$ & $\begin{array}{l}\text { To examine } \\
\text { compensation claims for } \\
\text { home healthcare }(\mathrm{HHC}) \\
\text { workers }\end{array}$ & $\begin{array}{l}\text { Industrial } \\
\text { insurance system } \\
\text { included state- } \\
\text { funded and self- } \\
\text { insured claims } \\
\text { from nursing } \\
\text { home, hospitals } \\
\text { and home care }\end{array}$ & $\begin{array}{l}\text { Claims incidence } \\
\text { calculated and expressed } \\
\text { for } 10,000 \text { FTE }\end{array}$ & $\begin{array}{l}\text { HHC claims rates consistently higher }(1,375 \\
\text { versus } 862 \text { for all workers). Most common } \\
\text { body region injured was back/spine. Most } \\
\text { common accident type was non-traumatic } \\
\text { MSD of neck, back and shoulder. Another } \\
\text { person was at least one source of the } \\
\text { accident in } 89 \% \text { of claims, overexertion } \\
\text { (physical) accounted for } 84 \% \text { of claims }\end{array}$ \\
\hline 17. & $\begin{array}{l}\text { Johansson, } \\
1995 \\
\text { [Sweden] }\end{array}$ & $\begin{array}{l}\text { Case } \\
\text { control } \\
\text { survey }\end{array}$ & $\begin{array}{l}\text { To describe the } \\
\text { psychosocial working } \\
\text { environment and physical } \\
\text { workload; assess MSD } \\
\text { (neck, shoulder, back) } \\
\text { symptoms prevalence, } \\
\text { estimate rate ratio of self- } \\
\text { reported MSD symptoms } \\
\text { for potential risk } \\
\text { indicators; analyse } \\
\text { effects of a set of } \\
\text { psychosocial and } \\
\text { physical variables; } \\
\text { examine the contribution } \\
\text { of a combination of } \\
\text { psychosocial work } \\
\text { environment and physical } \\
\text { workload }\end{array}$ & $\begin{array}{l}305 \text { home care } \\
\text { workers }(\mathrm{HCW})\end{array}$ & Questionnaire & $\begin{array}{l}\text { HCW had a relatively high prevalence of } \\
\text { MSD. Highest factors loading for } \\
\text { psychosocial was 'supervisor climate'. } \\
\text { Concerns about leadership and peer support } \\
\text { when working alone, M\&H of patients and } \\
\text { awkward working post } \\
\text { ures }\end{array}$ \\
\hline
\end{tabular}




\begin{tabular}{|c|c|c|c|c|c|c|}
\hline 18. & $\begin{array}{l}\text { Kalman \& } \\
\text { Andersson, } \\
2014 \\
\text { [Sweden] }\end{array}$ & $\begin{array}{l}\text { Exploratory } \\
\text { qualitative }\end{array}$ & $\begin{array}{l}\text { To observe and analyse } \\
\text { strategies for framing } \\
\text { intimate care in elderly } \\
\text { care services and how } \\
\text { the context of being an } \\
\text { everyday service } \\
\text { performed in the care } \\
\text { recipients home affects } \\
\text { the ways in which the } \\
\text { care is provided }\end{array}$ & $\begin{array}{l}23 \text { care recipients; } \\
7 \text { care workers }\end{array}$ & Field notes & $\begin{array}{l}\text { Framing helps to 'provide a distance that } \\
\text { regulates and characterises the interactions'. } \\
\text { General 'providing care in homes that were } \\
\text { not adapted for such work. As bathrooms } \\
\text { and toilets were really too narrow at times ... } \\
\text { use of toilet buckets or the washing of } \\
\text { intimate parts of the body might take place in } \\
\text { the ... Bedroom or sitting room'. }\end{array}$ \\
\hline 19. & $\begin{array}{l}\text { Kim et al, } \\
2010 \\
\text { [Canada] }\end{array}$ & $\begin{array}{l}\text { Prospectiv } \\
\text { e survey } \\
\text { exploratory } \\
\text { quant }\end{array}$ & $\begin{array}{l}\text { To determine the } 6 \\
\text { month incidence of MSD } \\
\text { (neck, shoulder, back) to } \\
\text { investigate the } \\
\text { association with the } \\
\text { physical demands of } \\
\text { work }\end{array}$ & $1198 \mathrm{HCW}$ & $\begin{array}{l}\text { Interview } \\
\text { Nordic questionnaire } \\
\text { Physical demand scale }\end{array}$ & $\begin{array}{l}55 \% \text { of } \mathrm{HCW} \text { found work often or always } \\
\text { demanding. The odds of developing new } \\
\text { MSD symptoms at } 6 \text { months were } \\
\text { significantly associated with increased } \\
\text { physical demands }\end{array}$ \\
\hline 20. & $\begin{array}{l}\text { Knibbe \& } \\
\text { Friele, } 1999 \\
\text { [Netherlands } \\
\text { ] }\end{array}$ & $\begin{array}{l}\text { Interventio } \\
\mathrm{n}\end{array}$ & $\begin{array}{l}\text { To evaluate if a self- } \\
\text { administered log detects } \\
\text { the nature and amount of } \\
\text { exposure to patient } \\
\text { handling induced by the } \\
\text { introduction of patient } \\
\text { lifting hoists in home care } \\
\text { nursing }\end{array}$ & $\begin{array}{l}355 \text { (baseline) } \\
\text { and } n=298 \text { post } \\
\text { intervention }\end{array}$ & $\begin{array}{l}\text { Nordic questionnaire. } \\
\text { Intervention: } \\
40 \text { patient hoists / training } \\
\text { / lift co-ordinators } \\
(\mathrm{n}=104) . \text { Evaluated with } \\
\text { Rated Perceived Exertion } \\
\text { and Lift counter (work } \\
\text { sampling) }\end{array}$ & Focus on M\&H of patient \\
\hline $\begin{array}{l}21 . \\
\star \star \star\end{array}$ & $\begin{array}{l}\text { Kraus et al, } \\
2002 \text { [US] }\end{array}$ & $\begin{array}{l}\text { Cluster } \\
\text { randomise } \\
\text { d trial }\end{array}$ & $\begin{array}{l}\text { To determine the effect of } \\
\text { back belt use on the } \\
\text { incidence of low back } \\
\text { injury in home attendants } \\
\text { in } 9 \text { agencies in New } \\
\text { York }\end{array}$ & $\begin{array}{l}\text { Three group: } \\
3,744 \text { (back belt); } \\
4,133 \text { (advice- } \\
\text { only); } \\
4,531 \text { (control) }\end{array}$ & $\begin{array}{l}\text { Questionnaire and injury } \\
\text { claim form }\end{array}$ & $\begin{array}{l}\text { Injuries were highest in control and advice } \\
\text { only groups; lowest in the back belt group. } \\
\text { Back belt v. Advice - not significant. } \\
\text { Back belt v. Control - significant. }\end{array}$ \\
\hline 22. & $\begin{array}{l}\text { Leff et al, } \\
2000 \text { [US] }\end{array}$ & $\begin{array}{l}\text { Case } \\
\text { series of } \\
\text { Quality } \\
\text { improveme } \\
\text { nt projects }\end{array}$ & $\begin{array}{l}\text { To report a variety of } \\
\text { performance } \\
\text { improvement strategies } \\
\text { over 2-3 years to reduce } \\
\text { employee injuries }\end{array}$ & $\begin{array}{l}\text { Licensed nursing } \\
\text { assistants at one } \\
\text { home care agency }\end{array}$ & \multicolumn{2}{|c|}{$\begin{array}{l}\text { Seven step improvement process: } 1 \text {. Current situation, } 2 \text {. Team objective, } \\
\text { 3. Analysis, } 4 \text {. Potential solutions, } 5 \text {. Results, } 6 \text {. Standardisation, } 7 \text {. } \\
\text { Future plans. }\end{array}$} \\
\hline
\end{tabular}




\begin{tabular}{|c|c|c|c|c|c|c|}
\hline $\begin{array}{l}23 . \\
* \star\end{array}$ & $\begin{array}{l}\text { Leiss, } 2012 \\
\text { [US] }\end{array}$ & Survey & $\begin{array}{l}\text { To examine whether the } \\
\text { protective effect of home } \\
\text { care/hospice work } \\
\text { experience was greater } \\
\text { for nurses who were } \\
\text { subjected to } 3 \text { typical } \\
\text { home care } \\
\text { circumstances; (1) level } \\
\text { of access to safety } \\
\text { devices and Personal } \\
\text { Protective Equipment; } \\
\text { (2) time pressure during } \\
\text { home visit; } \\
\text { (3) adverse conditions in } \\
\text { the homes }\end{array}$ & $\begin{array}{l}833 \text { home care } \\
\text { nurses }\end{array}$ & $\begin{array}{l}\text { Questionnaire (postal) blood } \\
\text { exposure rates per 100,000 } \\
\text { home visits via } 3 \text { routes for } \\
\text { blood exposure: } \\
\text { (1) needle stick, } \\
\text { (2) eyes, nose, mouth, } \\
\text { (3) on non-intact skin }\end{array}$ & $\begin{array}{l}\text { Experience in providing care in home } \\
\text { care/hospice enables nurses to } \\
\text { reduce the risk of blood exposure by } \\
3-7 x \text { compared with less experienced } \\
\text { workers. No difference in exposure to } \\
3 \text { routes, }\end{array}$ \\
\hline 24. & $\begin{array}{l}\text { Markkanen } \\
\text { et al, } 2007 \\
\text { [US] }\end{array}$ & $\begin{array}{l}\text { Exploratory } \\
\text { qualitative }\end{array}$ & $\begin{array}{l}\text { To characterise the work } \\
\text { experience and hazards } \\
\text { of home health care } \\
\text { (HHC) clinicians with a } \\
\text { focus on risk factors for } \\
\text { blood borne pathogen } \\
\text { exposures }\end{array}$ & $\begin{array}{l}17 \text { nurses and } 7 \\
\text { home aides }\end{array}$ & $\begin{array}{l}5 \text { focus groups; } \\
10 \text { in-depth interviews }\end{array}$ & $\begin{array}{l}\text { Disadvantages of HHC working } \\
\text { included abuse/violence, lack of } \\
\text { space/clutter, isolation (support and } \\
\text { safety), provision and use of } \\
\text { equipment and consumables, unsafe } \\
\text { disposal practices and M\&H of } \\
\text { patients } \\
\text { Not reporting due to fear of being } \\
\text { blamed, non-severe exposure } \\
\text { (scratch), fear of future job prospects, } \\
\text { takes too much time. } \\
\text { Safety features = retractable needles, } \\
\text { butterfly needles, needleless IV } \\
\text { systems, single medical device use } \\
\text { (numerous styles, lack of } \\
\text { standardisation. } \\
\text { Suggest that 'sharps injuries and } \\
\text { blood exposures can serve as a proxy } \\
\text { for safety and quality practices in } \\
\text { home care settings'. }\end{array}$ \\
\hline
\end{tabular}




\begin{tabular}{|c|c|c|c|c|c|c|}
\hline 25. & $\begin{array}{l}\text { McCaughey } \\
\text { et al, } 2012 \\
\text { [US] }\end{array}$ & $\begin{array}{l}\text { Secondary } \\
\text { data } \\
\text { analysis }\end{array}$ & $\begin{array}{l}\text { To examine the } \\
\text { relationship between } \\
\text { injuries and work } \\
\text { outcomes as reported by } \\
\text { home health aides } \\
\text { (HHAs) and (b) the likely } \\
\text { efficacy of employee } \\
\text { training and supervisor } \\
\text { support in reducing } \\
\text { worker risk of injury }\end{array}$ & 3377 HHAs & $\begin{array}{l}\text { National Home Health Aide } \\
\text { Survey. Number of injuries, } \\
\text { rating of training (preparedness), } \\
\text { supervisor support, worker \& } \\
\text { organisational outcomes }\end{array}$ & $\begin{array}{l}\text { The majority of HHAs did not report } \\
\text { injuries. Injured HHA had lower job } \\
\text { satisfaction, higher turnover and poor } \\
\text { employment and care quality } \\
\text { perceptions. }\end{array}$ \\
\hline 26. & $\begin{array}{l}\text { Meyer \& } \\
\text { Muntaner, } \\
1999 \text { [US] }\end{array}$ & $\begin{array}{l}\text { Exploratory } \\
\text { retrospecti } \\
\text { ve data } \\
\text { analysis of } \\
\text { compensat } \\
\text { ion claims }\end{array}$ & $\begin{array}{l}\text { To examine the } \\
\text { distribution, frequency } \\
\text { and costs of work-related } \\
\text { injury in home health } \\
\text { care workers }\end{array}$ & $\begin{array}{l}\text { Workers } \\
\text { compensation } \\
\text { data }\end{array}$ & $\begin{array}{l}\text { Extracted using occupational } \\
\text { codes }\end{array}$ & $\begin{array}{l}386 \text { injuries in } 12 \text { months (43 injuries } \\
\text { per } 1000 \text { workers). Most frequent } \\
\text { injuries were over exertion ( } 47 \%) \text {, } \\
\text { falls }(16 \%) \text { and motor vehicle (14) }\end{array}$ \\
\hline 27. & $\begin{array}{l}\text { Munck et al, } \\
2011 \\
\text { [Sweden] }\end{array}$ & $\begin{array}{l}\text { Exploratory } \\
\text { qualitative } \\
\text { phenomen } \\
\text { ological }\end{array}$ & $\begin{array}{l}\text { To describe district } \\
\text { nurses (DN) conceptions } \\
\text { of medical technology in } \\
\text { palliative care }\end{array}$ & $16 \mathrm{DNs}$ & Interviews & $\begin{array}{l}\text { Five descriptive categories: } \\
\text { (1) medical technology leads to } \\
\text { vulnerability (lack of continuity and } \\
\text { support in management of med } \\
\text { devices leads to uncertainty and } \\
\text { exposure in the home); } \\
\text { (2) medical technology demands } \\
\text { collaboration (between personnel, } \\
\text { patients and family; good peer } \\
\text { support e.g. joint home visits for new } \\
\text { tasks); } \\
\text { (3) medical technology demands self- } \\
\text { reliance (personal confidence and } \\
\text { experience); } \\
\text { (4) medical technology demands } \\
\text { awareness (requires patient safety } \\
\text { thinking, work environment e.g. } \\
\text { Lighting, access, working postures); } \\
\text { (5) medical technology provides } \\
\text { freedom for patients (independence } \\
\text { and increased opportunities) }\end{array}$ \\
\hline
\end{tabular}




\begin{tabular}{|c|c|c|c|c|c|c|}
\hline 28. & $\begin{array}{l}\text { Ono et al, } \\
1995 \\
\text { [Sweden] }\end{array}$ & $\begin{array}{l}\text { Exploratory } \\
\text { survey }\end{array}$ & $\begin{array}{l}\text { To describe the } \\
\text { nationwide occurrence of } \\
\text { work related MSD in } \\
\text { home care service } \\
\text { workers; to identify } \\
\text { relative risks and risk } \\
\text { factors of the injuries }\end{array}$ & $\begin{array}{l}105,006 \text { home } \\
\text { care service } \\
\text { workers }\end{array}$ & $\begin{array}{l}\text { Annual reported injury incidence } \\
\text { rate per } 1000 \text { workers }\end{array}$ & $\begin{array}{l}\text { Most common injuries are exertion } \\
(19.2) \text { and falls ( } 4.6) \text {. Handling } \\
\text { another person was the most } \\
\text { frequently reported to be the main risk } \\
\text { factor }(75 \%)\end{array}$ \\
\hline 29. & $\begin{array}{l}\text { Owen \& } \\
\text { Staehler, } \\
2003 \text { [US] }\end{array}$ & $\begin{array}{l}\text { Exploratory } \\
\text { survey }\end{array}$ & $\begin{array}{l}\text { To determine perceived } \\
\text { physical stressfulness of } \\
\text { home care tasks; } \\
\text { to identify what HHAs } \\
\text { and nurse observers } \\
\text { thought contributed to } \\
\text { making those tasks } \\
\text { stressful; } \\
\text { to develop ideas to } \\
\text { reduce back stress }\end{array}$ & $\begin{array}{l}33 \text { home care } \\
\text { aides and } 61 \\
\text { patients }\end{array}$ & $\begin{array}{l}\text { Likert scale rating of } \\
\text { stressfulness }(0-10)\end{array}$ & $\begin{array}{l}87 \% \text { tasks were patient handling or } \\
\text { providing direct patient care(mostly } \\
\text { alone, team for } 3 \text { tasks). Others were } \\
\text { furniture moving, making bed (see } \\
\text { Table 3). Greatest percentage of } \\
\text { ideas were for environmental change } \\
\text { e.g. design of bed }\end{array}$ \\
\hline 30. & $\begin{array}{l}\text { Pohjonen et } \\
\text { al, } 1998 \\
\text { [Finland] }\end{array}$ & $\begin{array}{l}\text { Interventio } \\
\mathrm{n}\end{array}$ & $\begin{array}{l}\text { To investigate the effects } \\
\text { and feasibility of an } \\
\text { ergonomic intervention } \\
\text { on the work content and } \\
\text { load of home care } \\
\text { workers }\end{array}$ & $\begin{array}{l}34 \text { (intervention); } \\
36 \text { (control) }\end{array}$ & $\begin{array}{l}12 \text { months participatory } \\
\text { ergonomics team work (group } \\
\text { problem solving) by analysing } \\
\text { the work with respect to content } \\
\text { and load. Measures included } \\
\text { pre/post work site assessment - } \\
\text { work ability index (WAI), work } \\
\text { sampling, heart rate and } \\
\text { postural analysis }\end{array}$ & $\begin{array}{l}\text { Significant reduction in postural } \\
\text { analysis; WAI in intervention group } \\
\text { did not change but in control group it } \\
\text { decreased significantly (worsened) }\end{array}$ \\
\hline 31. & $\begin{array}{l}\text { Quinn et al, } \\
2009 \text { [US] }\end{array}$ & Survey & $\begin{array}{l}\text { To quantify risks of } \\
\text { sharps injuries and other } \\
\text { blood and body fluid } \\
\text { exposures among home } \\
\text { care workers, to identify } \\
\text { risk factors and assess } \\
\text { the use of sharps within } \\
\text { safety features, } \\
\text { to evaluate under- } \\
\text { reporting in workplace- } \\
\text { based surveillance }\end{array}$ & $\begin{array}{l}1225 \text { home care } \\
\text { workers ( } 9 \\
\text { agencies and } 2 \\
\text { labour unions) }\end{array}$ & Questionnaire & $\begin{array}{l}\text { Sharps risk } 34 \text { per } 100 \text { FTE. } \\
\text { Nurses risk was twice that of aides } \\
\text { but similar annual exposure rates. } \\
\text { Nurses exposure during medical } \\
\text { processes (injections, fingers sticks, } \\
\text { blood draws); Aides mostly exposed } \\
\text { when disposing of used sharps. } \\
\text { Patient handling tasks contributed to } \\
\text { nearly } 75 \% \text { of exposures for aides. } \\
\text { Aggressive/unco-operative patients } \\
\text { were contributing factor for both } \\
\text { nurses and aides. Risks higher with } \\
\text { agency than permanent staff. }\end{array}$ \\
\hline
\end{tabular}




\begin{tabular}{|c|c|c|c|c|c|c|}
\hline 32. & $\begin{array}{l}\text { Simon et al, } \\
2008 \\
\text { [Germany] }\end{array}$ & $\begin{array}{l}\text { Secondary } \\
\text { data } \\
\text { analysis }\end{array}$ & $\begin{array}{l}\text { To investigate physical } \\
\text { and psychosocial risk } \\
\text { factors associated with } \\
\text { neck and back disability } \\
\text { in nursing and assess the } \\
\text { role of the type of health } \\
\text { care institution within } \\
\text { different countries }\end{array}$ & 2606 home care & $\begin{array}{l}\text { Four-item scale for disability, } \\
\text { physical risk factors and 5-point } \\
\text { psychosocial factors scale }\end{array}$ & $\begin{array}{l}\text { Proportion of staff without disability is } \\
\text { highest in home care }(62.3 \%) \text {. In } \\
\text { home care institutions, the conditions } \\
\text { assessed were the least adverse in } \\
\text { comparison to hospital and nursing } \\
\text { home settings. }\end{array}$ \\
\hline 33. & $\begin{array}{l}\text { Sims-Gould } \\
\text { et al, 2013 } \\
\text { [Canada] }\end{array}$ & $\begin{array}{l}\text { Exploratory } \\
\text { qualitative }\end{array}$ & $\begin{array}{l}\text { To study the nature of } \\
\text { crises experienced by } \\
\text { Home Support Workers } \\
\text { (HSW) }\end{array}$ & 118 HSWs & Interviews & $\begin{array}{l}91 \% \text { of HSWs have experienced a } \\
\text { crisis when providing care both to } \\
\text { themselves and their clients. Normal } \\
\text { unpredictability related to scheduling } \\
\text { and range of client conditions, } \\
\text { personalities, and situations on a daily } \\
\text { basis e.g. split shifts, casual work, last } \\
\text { minute cancellations and sickness. } \\
\text { Management of crises by } 3 \text { routes } \\
\text { (1) follow agency protocol, call } 911 \text { or } \\
\text { agency, (2) bend/break rules to } \\
\text { personalise care, (3) work to avert } \\
\text { crisis by addressing safety risks (e.g. } \\
\text { change light bulb) }\end{array}$ \\
\hline 34. & $\begin{array}{l}\text { Skoglind- } \\
\text { Ohman \& } \\
\text { Kjellberg, } \\
2011 \\
\text { [Sweden] }\end{array}$ & $\begin{array}{l}\text { Exploratory } \\
\text { pilot } \\
\text { qualitative }\end{array}$ & $\begin{array}{l}\text { To explore whether home } \\
\text { care service personnel } \\
\text { used knowledge and } \\
\text { skills in transfer } \\
\text { technique in their daily } \\
\text { work; } \\
\text { to identify factors that } \\
\text { could hinder/support their } \\
\text { use }\end{array}$ & $\begin{array}{l}12 \text { participants in } \\
2 \text { focus groups, } \\
36 \text { interviews }\end{array}$ & Interviews and focus groups & $\begin{array}{l}\text { Four themes. } \\
\text { (1) experience and use of knowledge } \\
\text { in transfer techniques; } \\
\text { (2) supporting factors for use of safe } \\
\text { work techniques - communication \& } \\
\text { co-operation; } \\
\text { (3) obstacles and use of safe work } \\
\text { techniques; } \\
\text { (4) supporting hindering factors for } \\
\text { use of safe work techniques - lack of } \\
\text { participation in planning workload and } \\
\text { informal sharing of client group and } \\
\text { status }\end{array}$ \\
\hline
\end{tabular}




\begin{tabular}{|c|c|c|c|c|c|c|}
\hline 35. & $\begin{array}{l}\text { Swedberg et } \\
\text { al, } 2013 \\
\text { [Sweden] }\end{array}$ & $\begin{array}{l}\text { Exploratory } \\
\text { qualitative }\end{array}$ & $\begin{array}{l}\text { To investigate the work } \\
\text { experience of Health } \\
\text { Care }(\mathrm{HC}) \text { assistants and } \\
\text { explore how they } \\
\text { manage when delivering } \\
24 / 7 \text { care to patients with } \\
\text { substantial care needs } \\
\text { outside the security that } \\
\text { comes with a hospital } \\
\text { setting }\end{array}$ & $19 \mathrm{HC}$ assistants & $\begin{array}{l}12 \text { Interview and observation; } 7 \\
\text { Observation only }\end{array}$ & $\begin{array}{l}\text { Themes (1) barriers, competence gap } \\
\text { - not trained for all the things they } \\
\text { (clients) want us to do. } \\
\text { (2) Compensating processes. Day-to- } \\
\text { day learning including collegial } \\
\text { (situated) learning, reflection in action. } \\
\text { Balancing relations with the patients, } \\
\text { with support from colleagues, self- } \\
\text { managing with informal leadership } \\
\text { (team support), navigating the patient } \\
\text { care system }\end{array}$ \\
\hline 36. & $\begin{array}{l}\text { Szeto et al, } \\
2013 \text { [Hong } \\
\text { Kong] }\end{array}$ & $\begin{array}{l}\text { Interventio } \\
\mathrm{n}\end{array}$ & $\begin{array}{l}\text { To see if intervention } \\
\text { effect can be sustained } \\
\text { for longer periods of time; } \\
\text { to see if program is } \\
\text { effective as both } \\
\text { secondary and primary } \\
\text { intervention for } \\
\text { community nurses }\end{array}$ & $\begin{array}{l}\text { Pilot intervention } \\
\mathrm{n}=15, \\
\text { Control } \mathrm{n}=12, \\
\text { Intervention } \mathrm{n}=23\end{array}$ & $\begin{array}{l}8 \text { week ergonomic program with } \\
\text { expert advice, work and } \\
\text { equipment modification (e.g. } \\
\text { Portable back packs), M\&H } \\
\text { training, exercise and Display } \\
\text { screen Assessment training }\end{array}$ & $\begin{array}{l}\text { Reduction in symptom scores and } \\
\text { increase in functional outcome } \\
\text { measures Both post intervention and } \\
\text { at } 12 \text { months }\end{array}$ \\
\hline $\begin{array}{l}37 . \\
*\end{array}$ & $\begin{array}{l}\text { Wipfli et al, } \\
2012 \text { [US] }\end{array}$ & Exploratory & $\begin{array}{l}\text { To address research } \\
\text { gaps on hazardous } \\
\text { exposures among HCWs } \\
\text { and evaluate the } \\
\text { generality of prior } \\
\text { findings }\end{array}$ & $\begin{array}{l}7 \text { focus groups } \\
\text { (53 HCWs) }\end{array}$ & $\begin{array}{l}\text { Work related injury and illness } \\
\text { database }\end{array}$ & $\begin{array}{l}\text { Lost injury time }=352 / 10,000 \text { FTE } \\
\text { (compared with US ave. } 117 \text { ). } \\
\text { Ave time lost }=27.9 \text { days ( } 33 \% \text { back } \\
\text { injuries, followed by shoulder, neck } \\
\text { and knee). } \\
\text { Strains when lifting, moving clients } \\
51 \% \text { (falls } 23 \% \text { ). Workers opinions } \\
\text { were aligned with injury statistics with } \\
\text { respect to strains. 'HCWs are } \\
\text { vulnerable to work overload as they } \\
\text { feel burdened with too many tasks to } \\
\text { accomplish during allotted work time } \\
\text { and feel pressure from clients to } \\
\text { provide extra-role social support'. }\end{array}$ \\
\hline
\end{tabular}




\section{Synthesis}

The risk factors have been grouped using the modified model of Human Factors and Ergonomics of health care in the home from Beer et al (2014) to represent the roles of both patients and caregivers in the system. The groups are environments (health policy, community, physical and social), artefacts (equipment and technology), tasks (clinical procedures, work schedules) and care recipient/provider.

\subsection{Environments (health policy, community, physical and social)}

Health policies introduce risks when the policies, procedures and guidelines are inadequate (strong evidence: Dellve et al, 2003; moderate evidence: Sims-Gould et al, 2013; Swedberg et al, 2013). This can include a lack of standardisation in paperwork and computer interfaces, and inadequate care plans (strong evidence: Cheung et al, 2006; moderate evidence: Beer et al, 2014; Kalman \& Andersson, 2014; Munck et al, 2011; Sims-Gould et al, 2013; limited evidence: Czuba et al, 2012, Hoff, 2013). These problems are exacerbated with inadequate leadership (strong evidence: Dellve et al, 2003; moderate evidence: Swedberg et al, 2013; limited evidence: Johansson, 1995; McCaughey et al, 2012) and a lack of, or insufficient, training (strong evidence: Dellve et al, 2003; moderate evidence: Kalman \& Andersson, 2014; limited evidence: Swedberg et al, 2013; Czuba et al, 2012; McCaughey et al, 2012)

The physical environment of care can introduce risk factors associated with permanent (building design and layout) and temporary factors (e.g. clutter and obstacles). The permanent physical environment issues included cramped conditions (strong evidence: Hale \& Piggot, 2005; moderate evidence: Craven et al, 2012; Kalman \& Andersson, 2014; Markkanen et al, 2007; Munck et al, 2011; Quinn et al, 2009; Skoglind-Ohman \& Kjellberg, 2011; Swedberg et al, 2013), poor lighting (moderate evidence: Beer et al, 2014; Leiss, 2012; Munck et al, 2011), poor access to stairs (moderate evidence: Kim et al, 2010) and unsafe flooring (limited evidence: Conneeley, 1998). There are also less permanent risk factors associated with clutter and obstacles (moderate evidence: Beer et al, 2014; Leiss, 2012; Markkanen et al, 2007; Quinn et al, 2009; Skoglind-Ohman \& Kjellberg, 2011) and awkward working positions for clinical, IT and writing tasks (strong evidence: Cheung et al, 2006; Dellve et al, 2003; Ono et al, 1995; Brulin et al, 2001; moderate evidence: Kim et al, 2010; Munck et al, 2011; Pohjonen et al, 1998; Quinn et al, 2009; Simon et al, 2008). 
The social environment issues range from additional tasks to distractions from pets, children and televisions (strong evidence: Cheung et al, 2006; Hale \& Piggot, 2005; moderate evidence: Leiss, 2012; Sims-Gould et al, 2013; limited evidence: Denton et al, 2002) through to issues of cleanliness and insect and rodent infestations (moderate evidence: Sims-Gould et al, 2013; Quinn et al, 2009; limited evidence: Denton et al, 2002). The close interaction can lead to additional requests from patients which were not on the treatment plan and/or outside the caregiver job description (moderate evidence: Beer et al, 2014; Skoglind-Ohman \& Kjellberg, 2011; Swedberg et al, 2013; limited evidence: Denton et al, 2002). The most serious risk is perhaps that of abuse and violence from patients and their family (strong evidence: Craib et al, 2007; Dellve et al, 2003; Howard \& Adams, 2010; moderate evidence: Craven et al, 2012; Galinsky et al, 2010; Markkanen et al, 2007; SimsGould et al, 2013).

\subsection{Artefacts (equipment and technology)}

Beer et al (2014) use the term 'artefacts' to include equipment, technology (medical devices) and supplies (consumables). Evidence was found that identified physical risks associated with inadequate and missing equipment, e.g. lifting or bathing equipment which was the incorrect size and/or weight capacity for the patient (strong evidence: Hale \& Piggot, 2005; moderate evidence: Craven et al, 2012; Faucett et al, 2013; Leiss, 2012; Pohjonen et al, 1998; Simon et al, 2008; Sims-Gould et al, 2013) and a lack of support for maintenance and training in medical devices (moderate evidence: Munck et al, 2011).

The supply of different or new medical devices (model or supplier) could introduce safety issues with respect to use and set up of, for example ventilators, oxygen, infusion pumps, suction, and blood glucose meters (moderate evidence: Beer et al, 2014; Markkanen et al, 2007). The quantity and quality of supplies and consumables

e.g. incontinence pads, bandaging, gloves can introduce and exacerbate physical interaction risks, e.g. leakage of pads (moderate evidence: Markkanen et al, 2007; Craven et al, 2012).

\subsection{Tasks}

Tasks are described by Beer et al (2014) as ranging from 'simple tasks such as taking a care recipient on a walk to cognitively-challenging tasks (e.g., managing 
complex medication regimens) and physically-challenging tasks (e.g., bathing, toileting, transfer)'. This group includes the degree of collaboration (working alone or as a team), timing, duration and work schedules.

Evidence was found for risks associated with inadequate peer (team) support (strong evidence: Dellve et al, 2003); Brulin et al, 2001; moderate evidence: Markkanen et al, 2007; Munck et al, 2011; Skoglind-Ohman \& Kjellberg, 2011; Swedberg et al, 2013; limited evidence: Denton et al, 2002; Johansson, 1995), and security/safety issues associated with working alone (strong evidence: Hale \& Piggot, 2005; moderate evidence: Beer et al, 2014; Markkanen et al, 2007; Swedberg et al, 2013). Problems with workload planning were reported as contributing to rostering problems (strong evidence: Cheung et al, 2006; Dellve et al, 2003; Brulin et al, 2001; moderate evidence: Pohjonen et al, 1998; Skoglind-Ohman \& Kjellberg, 2011; Swedberg et al, 2013; limited evidence: Czuba et al, 2012; Denton et al, 2002; Hoff, 2013; Johansson, 1995; Leff et al, 2000), time pressures and feeling rushed (strong evidence: Dellve et al, 2003; moderate evidence: Craven et al, 2012; Leiss, 2012; Quinn et al, 2009). This could contribute to cognitive risks associated with the physical interactions when reconciling medication (moderate evidence: Beer et al, 2014). For clinical procedures, disposal practices were reported to present safety risks for dressings (moderate evidence: Markkanen et al, 2007), sharps (including sharps in bed linen) and needle stick injuries (strong evidence: Alamgir et al, 2007; Craib et al, 2007; moderate evidence: Galinsky et al, 2010; Leiss, 2012; Markkanen et al, 2007; Quinn et al, 2009).

Physical workload has been extensively researched for both moving and handling household objects, for example moving furniture to gain access to the patient when changing a leg dressing (moderate evidence: Beer et al, 2014; limited evidence: Owen \& Staehler, 2003) and patients (strong evidence: Alamgir et al, 2007; Craib et al, 2007; Howard \& Adams, 2010; Kraus et al, 2002; Meyer \& Muntaner, 1999; Ono et al, 1995; Brulin et al, 2001; moderate evidence: Craven et al, 2012; Faucett et al, 2013; Galinsky et al, 2010; Kim et al, 2010; Markkanen et al, 2007; Quinn et al, 2009; Simon et al, 2008; Szeto et al, 2013; limited evidence: Brown \& Mulley, 1997; Conneeley, 1998; Czuba et al, 2012; Denton et al, 2002; Johansson, 1995; Knibbe \& Friele, 1999; Leff et al, 2000; Owen \& Staehler, 2003; Wipfli et al, 2012).

\subsection{Patient and Caregiver}


This group was used by Beer et al (2014) to refer to the demographic and personal characteristics of both patient (care recipient) and caregiver. Examples from the literature include physical interactions which exposed the caregiver to infectious diseases (e.g. hepatitis, HIV, flu, TB, measles and chickenpox; EU-OSHA, 2014; strong evidence: Craib et al., 2007; moderate evidence: Leiss, 2012; limited evidence: Denton et al, 2002).

\section{Discussion}

This review has focussed on the physical interactions between patients and caregivers. The search produced over 1600 references covering a wide range of topics, leading to more detailed (emerging) exclusion criteria as the scope of physical interactions was explored. This resulted in papers on risks associated with care by informal caregivers being excluded due to the difference in status of caregivers with respect to organisational policies, procedures and training (Brown and Mulley, 1997). In Europe employed community caregivers are covered by the European Framework Directive on Safety and Health at Work (Directive 89/391 EEC; EU-OSHA, 2014). The directive obliges employers to take appropriate preventative measures to make work safer and healthier. However, self-employed and domestic workers are not covered by EU OSH legislation, so the organisation of care provision as basic and advanced levels may change an employer's obligations with respect to the safety of the work activities and working environment.

The quality appraisal for each paper is listed in Table 2 and summarised by topic in section 7. Most topics have several papers giving strong, moderate and limited evidence. The topics with strong evidence from at least 2 papers relate to risks associated with awkward working positions, social environment issues (additional tasks and distractions), abuse and violence, inadequate team (peer) support, problems with workload planning, needle stick injuries and physical workload (moving and handling patients).

The organisation of care (health policy) was found to be more complex than acute care provision with respect to leadership and peer support. This could contribute to risks for both patients and caregivers when visits were shortened due to concerns about abuse, physically challenging tasks (moving and handling), missing/inadequate equipment and consumables (Galinsky et al, 2010). There could 
also be pressure from the patient (and family) to deliver care when the caregiver did not feel that they had the appropriate knowledge, training and skills (Faucett et al, 2013; Munck et al, 2011). Caregivers could feel very isolated and unsupported, especially if the equipment and consumables needed to provide the care were missing, inadequate or had changed (e.g. different medical device). This contributed to cognitive risks relating to stress and decision-making about medication reconciliation and medical device use, e.g. whether to use wrong size slings with moving and handling hoists (lifts).

The extensive literature on moving and handling included over-exertion (Galinsky et al, 2012) relating to physical interactions with both patients and furniture. Patient care can include lifting/transferring without help, bathing, putting on shoes and lifting legs, pushing in wheelchair, supporting when walking; domestic tasks can include cleaning the bathroom, moving boxes or furniture, making beds, climbing stairs, standing in one place for a long time (Kim et al, 2010). Caregivers were reported to address issues of clutter, obstacles and lack of space by moving and rearranging furniture; however, when this was not possible there were reports of awkward working postures (Cheung et al, 2006) and confined spaces. A report (EU-OSHA, 2014) has suggested that 'about 40-48 \% of a home healthcare worker's time may be spent in poor posture combinations, including bent forward and twisted postures, which are associated with shoulder, neck and back problems'. Brown and Mulley (1997) commented that providing assistance using the toilet was 'the single most difficult task as it involved a number of lifts and manoeuvres, timing is unpredictable and is often done without extra assistance'.

For some of the safety risks it was not clear whether the location introduced additional risks (e.g. sharps disposal and medication reconciliation) or if these would be similar in other settings. Some of risk factors which are specific to home care include the working environment, worker safety (isolation and peer support), equipment provision and maintenance, and supply and disposal of clinical consumables. Other physical interactions occur in both home care and care facilities but the tasks are more complex in home care, for example limited space for moving and handling tasks and poor lighting/flooring etc. Craven et al (2012) stated that 'quality care in the home is dependent on having a safe environment to receive and provide care, despite the fact that the 'home space' of each client is highly variable'. 
The issue of time provision and feeling rushed has recently been discussed in the UK, where the National Institute for Health and Care Excellence (NICE, 2015) has published recommendations that person-centred home care should be planned to deliver safe, high quality services. This includes a suggestion that scheduling of home care visits should allow for generally 'half an hour with each person'.

The limitations of the review process include the use of emerging exclusion criteria; to address this, the entire data base was reviewed with the final exclusion criteria to ensure that all possible references were included/excluded. The decision to include all study types but to limit the papers to publications in peer reviewed journals rather than grey literature and conference proceedings may have excluded research from some topic areas but it was felt necessary to set a high publication standard for inclusion to generate trustworthy results and recommendations. Two critical appraisal tools were used to address individual limitations. The Downs and Black (1998) checklist has been widely used to appraise healthcare research but the more recent Mixed Methods Appraisal Tool (Pluye et al 2009, 2011) has been validated for different study types and, although less detailed, provides a useful categorization approach for critical appraisal.

\section{Conclusion}

As home care increases, there is a need to ensure the safety of both patients and caregivers with an understanding of the risks for physical interactions and tasks. This review has summarised the wide range of factors associated with the environment of care (health policy, physical and social), equipment and tasks (clinical practice). Although some of the safety risks are present wherever the tasks are carried out (e.g. sharps disposal and medication reconciliation) but home care seems to introduce additional risks associated with the working environment, isolation and peer support, equipment provision and maintenance, and supply and disposal of clinical consumables. As this care sector grows, it will become increasingly important to manage risks and plan safer care delivery systems or, it is suggested, the provision of services may be withdrawn formally (unsafe environment) and/or informally as caregivers shorten visits and fail to deliver some aspects of care. 


\section{References}

Alamgir, H., Cvitkovich, Y., Yu, S., Yassi, A. 2007. Work-related injury among direct care occupations in British Columbia, Canada. Occupational and Environmental Medicine. 64, 11, 769-775.

Beer, J.A., Mcbride, S.E., Mitzner, T.L., Rogers, W.A. 2014. Understanding challenges in the front lines of home health care: A human-systems approach. Applied Ergonomics. 45, 16871699.

Brown, A.R., Mulley, G.P. 1997. Injuries sustained by caregivers of disabled elderly people. Age and Ageing. 26, 1, 21-23.

Brulin, C., Höög, J., Sundelin, G. 2001. Psychosocial predictors for shoulder/neck and low back complaints among home care personnel. Advances in Physiotherapy. 3, 4, 169-178. Cheung, K., Gillen, M., Faucett, J., Krause, N. 2006. The prevalence of and risk factors for back pain among home care nursing personnel in Hong Kong. American Journal of Industrial Medicine. 49, 1, 14-22.

Conneeley, A.L. 1998. The impact of the manual handling operations regulations 1992 on the use of hoists in the home: The patient's perspective. British Journal of Occupational Therapy. 61, 1, 17-21.

Craib, K. J. P., Hackett, G., Back, C., Cvitkovich, Y., Yassi, A. 2007. Injury rates, predictors of workplace injuries, and results of an intervention program among community health workers. Public Health Nursing. 24, 2, 121-131.

Craven, C., Byrne, K., Sims-Gould, J., Martin-Matthews, A. 2012. Types and patterns of safety concerns in home care: Staff perspectives. International Journal for Quality in Health Care. 24, 5, 525-531.

Czuba, L.R., Sommerich, C.M., Lavender, S.A. 2012. Ergonomic and safety risk factors in home health care: Exploration and assessment of alternative interventions. Work. 42, 3, 341353.

Davin, B., Paraponaris, A., Verger, P. 2005. Demographic and socioeconomic factors associated with needs for home assistance among community-dwelling elderly: A study from the French home survey handicaps-disabilities-dependence. Revue d'Epidemiologie et de Sante Publique. 53. 5, 509-524.

Dellve, L., Lagerström, M., Hagberg, M. 2003. Work-system risk factors for permanent work disability among home-care workers: A case-control study. International Archives of Occupational and Environmental Health. 76, 3, 216-224.

Denton, M.A., Zeytinoglu, I.U., Davies, S. 2002. Working in Clients' Homes: The impact on the Mental Health and Well-Being of Visiting Home Care Workers. Home Health Care Quarterly. 21, 1, 1-27 
Department of Health. 2012. Caring for our future: reforming care and support. Norwich: The Stationary Office.

Downs, S.H., Black, N. 1998. The Feasibility of Creating a Checklist for the Assessment of the Methodological Quality both of Randomised and Non-Randomised Studies of Health Care Interventions. Journal of Epidemiological Community Health. 52, 377-384

Duke, M., Botti, M., Hunter, S. 2012. Effectiveness of pain management in hospital in the home programs. Clinical Journal of Pain. 28, 3, 187-194.

EU-OSHA European Agency for Occupational Safety \& Health at Work. 2014. Current and emerging issues in the healthcare sector, including home and community care. Bilbao, Spain: EU-OSHA.

Faucett, J., Kang, T., Newcomer, R. 2013. Personal Service Assistance: Musculoskeletal Disorders and Injuries in Consumer Directed Home Care. American Journal of Industrial Medicine. 56, 454-468.

Galinsky, T., Feng, H. A., Streit, J., Brightwell, W., Pierson, K., Parsons, K., et al. 2010. Risk factors associated with patient assaults of home healthcare workers. Rehabilitation Nursing. 35, 5, 206-215.

Hale, L. A., Piggot, J. 2005. Exploring the content of physiotherapeutic home-based stroke rehabilitation in New Zealand. Archives of Physical Medicine \& Rehabilitation. 86, 10, 19931940.

Hignett, S., Crumpton, E., Alexander, P., Ruszala, S., Fray, M., Fletcher, B. 2003. EvidenceBased Patient Handling: Tasks, Equipment and Interventions. London: Routledge Hoff, T. 2013. Medical Home Implementation: A Sensemaking Taxonomy of Hard and Soft Best Practices. The Milbank Quarterly. 91, 4, 771-810

Howard, N., Adams, D. 2010. An analysis of injuries among Home Health Care workers using Washington State Workers' Compensation Claims database. Home Health Care Services Quarterly. 29, 2, 55-74.

HSE 2009. Working Alone. Health and safety guidance on the risks of lone working. INDG73(rev3) http://www.hse.gov.uk/pubns/indg73.htm (accessed 30 June 2015) HSE 2014. Health and Safety in Care Homes. HSG022. http://www.hse.gov.uk/pubns/priced/hsg220.pdf (accessed 24 June 2014) Johansson, J.A.. 1995. Psychosocial work factors, physical work load and associated musculoskeletal symptoms among home care workers. Scandinavian Journal of Psychology. 36, 113-129.

Kalman, H., Andersson, K. 2014. Framing of intimate care in home care services. European Journal of Social Work. 17, 3, 402-414. 
Kim, I-H., Geiger-Brown, J., Trinkoff, A., Muntaner, C. 2010. Physically demanding workloads and the risks of musculoskeletal disorders in homecare workers in the USA. Health and Social Care in the Community. 18, 5, 445-455.

Knibbe, J.J., Friele, R.D. 1996. Prevalence of back pain and characteristics of the physical workload of community nurses. Ergonomics. 39, 2, 186-198.

Knibbe, J.J., Friele, R D. 1999. The use of logs to assess exposure to manual handling of patients, illustrated in an intervention study in home care nursing. International Journal of Industrial Ergonomics, 24, 4, 445-454.

Kraus, J.F., Schaffer, K.B., Rice, T., Maroosis, J., Harper, J. 2002. A field trial of back belts to reduce the incidence of acute low back injuries in New York City home attendants. International Journal of Occupational and Environmental Health. 8, 2, 97-104. Leff, E.W., Hagenbach, G.L., Marn, K.K. 2000. Preventing home health nursing assistant back and shoulder injuries. Joint Commission Journal on Quality Improvement. 26, 10, 587600.

Leh, S.K. 2011. Nursing students' preconceptions of the community health clinical experience: Implications for nursing education. Journal of Nursing Education. 50, 11, 620627.

Leiss, J. 2012. Work Experience, Work Environment, and Blood Exposure among Home Care and Hospice Nurses. Industrial Health. 50, 521-528.

Markkanen, P., Quinn, M., Galligan, C., Chalupka, S., Davis, L., Laramie, A. 2007. There's no place like home: A qualitative study of the working conditions of home health care providers. Journal of Occupational \& Environmental Medicine. 49, 3, 327-337.

McCaughey, D., McGhan, G., Kim, J., Brannon, D., Leroy, H., Jablonski, R. 2012. Workforce Implications of Injury among Home Health Workers: Evidence from the National Home Health Survey. The Gerontologist. 52, 4, 493-505.

Meyer, J., Muntaner, C. 1999. Injuries in Home Health Care Workers: An Analysis of Occupational Morbidity from a State Compensation Database. American Journal of Industrial Medicine. 35, 295-301.

Miller, E., Cameron, K. 2011. Challenges and benefits in implementing shared inter-agency assessment across the UK: A literature review. Journal of Interprofessional Care. 25, 1, 3945.

Munck, B., Fridlund, B., Martensson, J. 2011. District nurses' conceptions of medical technology in palliative homecare. Journal of Nursing Management. 19, 7, 845-854. NICE. 2015. NG 21 Home care: delivering personal care and practical support to older people living in their own homes. http://nice.org.uk/guidance/ng21 (accessed 15 October 2015). 
Ono, Y., Lagerström, M., Hagberg, M., Linden, A., Malker, B. 1995. Reports of work related musculoskeletal injury among home care service workers compared with nursery school workers and the general population of employed women in Sweden. Occupational and Environmental Medicine. 52, 10, 686-693.

Owen, B.D., Staehler, K.S. 2003. Decreasing back stress in home care. Home Healthcare Nurse. 21, 3, 180-186.

Pluye, P., Gagnon, M-P., Griffiths, F., Johnson-Lafleur, J. 2009. A scoring system for appraising mixed methods research and concomitantly appraising qualitative, quantitative and mixed methods primary studies in Mixed Studies Reviews. Clinical Research. 46, 4, 529-546.

Pluye, P., Robert, E., Cargo, M., Bartlett, G., O'Cathain, A., Griffiths, F., Boardman, F., Gagnon, M.P., \& Rousseau, M.C. 2011. Proposal: A mixed methods appraisal tool for systematic mixed studies reviews. Retrieved on [16 Dec 2014] from http://mixedmethodsappraisaltoolpublic.pbworks.com.

Pohjonen, T., Punakallio, A., Louhevaara, V. 1998. Participatory Ergonomics for reducing load and strain in home care work. International Journal of Industrial Ergonomics. 21, 345352.

Quinn, M.M., Markkanen, P.K., Galligan, C.J., Kriebel, D., Chalupka, S.M., Kim, H., et al. 2009. Sharps injuries and other blood and body fluid exposures among home health care nurses and aides. American Journal of Public Health. 99 Suppl 3, S710-717.

Simon, M., Tackenberg, P., Nienhaus, A., Estryn-Behar, M., Conway, P. M., Hasselhorn, H. 2008. Back or neck-pain-related disability of nursing staff in hospitals, nursing homes and home care in seven countries-results from the European NEXT-study. International Journal of Nursing Studies. 45, 1, 24-34.

Sims-Gould, J., Byrne, K., Beck, C., Martin-Matthews, A. 2013. Workers' Experiences of Crises in the Delivery of Home Support Services to Older Clients: A qualitative study. Journal of Applied Gerontology. 32, 1, 31-50.

Skoglind-Ohman, I., Kjellberg, K. 2011. Factors that influence the use of safe patient transfer technique in home care service. International Journal of Occupational Safety \& Ergonomics. $17,4,433-444$.

Swedberg, L., Chiriac, E. H., Tornkvist, L., Hylander, I. 2013. From risky to safer home care: Health care assistants striving to overcome a lack of training, supervision, and support. International Journal of Qualitative Studies on Health and Well-being. 8, 20758. Szeto, G.P.Y., Wong, K.T., Law, K.Y., Lee, E.W.C. 2013. A study of spinal kinematics in community nurses performing nursing tasks. International Journal of Industrial Ergonomics. 43, 3, 203-209. 
Taylor, B. J., Donnelly, M. 2006. Risks to home care workers: Professional perspectives. Health, Risk \& Society. 8, 3, 239-256.

Torjesen, I. 2015. Home care visits should be at least 30 minutes long, NICE says. BMJ 351:h5057

WHO 2008. The Solid Facts: Homecare in Europe.

http://www.euro.who.int/ data/assets/pdf file/0005/96467/E91884.pdf [accessed 11 June 2015]

Wipfli, B., Olson, R., Wright, R.R., Garrigues, L., Lees, J. 2012. Characterising Hazards and Injuries among Home Care Workers. Home Healthcare Nurse. 30, 7, 387-393. 